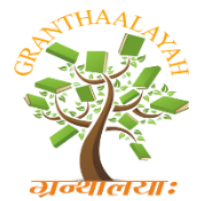

\author{
INTERNATIONAL JOURNAL OF RE
GRANTHAALAYAH \\ A knowledge Repository
}

Science

\title{
PROBING THE NATURE AND CHARACTERISTICS OF ACTIVE MUD VOLCANIC CLUSTERS IN MAKRAN COASTAL ZONE, PAKISTAN
}

\author{
Waseem Khan ${ }^{* 1}$, Mahnoor Mirwani ${ }^{2}$ \\ ${ }^{*}$ School of Earth Sciences and Geological Engineering, Sun Yat Sen University, Zhuhai, China \\ ${ }^{2}$ Department of Civil Engineering, Balochistan University of Information Technology, \\ Engineering and Managements Sciences, Quetta, Pakistan
}

\begin{abstract}
Makran Subduction Zone is formed in Late Cretaceous. It is divided into Eastern Makran at the southern edge of Helmand Block in Pakistan and the Western Makran at the southern edge of Lut Block in Iran. The velocity of convergence in Eastern and Western Makran are $42.0 \mathrm{~mm} / \mathrm{yr}$ and $35.6 \mathrm{~mm} / \mathrm{yr}$ repectively. Both segments are bound by strike-slip faults e.g. Ornach-Nal left lateral fault in the east and Minab right lateral in the west. Stratigraphically, the zone comprises Formations of ages ranging from Cretaceous to Holocene. In the Eastern Makran, most of the mud volcanoes are located along strike which include Awaran and Sipai-sing, Chandragup, Gwadar, Jabel-e-Gurab, Khandawari, Kund Malir, Ormara and Offshore mud volcanoes. The continental margin of Makran is an ideal environment of Oxygen Maximum Zone which receives organic rich matters in its sediments by marine organisms. Several assisting factors play significant roles in erupting the fluid and methane gasses through the mud vents in Makran Coastal Region such as tectonic stresses, oil, saltwater, and transmitting freshwater in the sedimentary environments.
\end{abstract}

Keywords: Makran Subduction Zone; Helmand block; Lut block; Eastern Makran; Western Makran; Active Mud Volcanoes.

Cite This Article: Waseem Khan, and Mahnoor Mirwani. (2020). "PROBING THE NATURE AND CHARACTERISTICS OF ACTIVE MUD VOLCANIC CLUSTERS IN MAKRAN COASTAL ZONE, PAKISTAN." International Journal of Research - Granthaalayah, 8(3), 214-222. https://doi.org/10.29121/granthaalayah.v8.i3.2020.145.

\section{Introduction}

An approximate length of the coast-line can be $1050 \mathrm{~km}$ in Pakistan out of which Makran occupied more than $600 \mathrm{~km}$. Makran Accretionary wedge represents unique geology and morphological characters as it belongs to the only remnant of Tethyan Ocean i.e., Makran Subduction Zone. Makran Subduction is an active region and has a similar mountainous feature that of Northern Pakistan and Himalayas (Tabrez et al., 2002). The geomorphological figures and features have been developed and still in progress by the northern movement of Arabian Plate in south and IndoPak Plate progression on the east. The southern margin of Asian Plate in Pakistan and Iran is 
marked by the Tethyan remain. Two known blocks in Pakistani and Iranian region, namely the Helmond in the east and the Lut blocks in the west are the Gondwanan accreted terraces (Fig. 1). Once, an area of Neo-Tethyian divided the Helmand and Lut Blocks which foundered underneath the Afghan Block (Helmand Block) (Tirrul el al., 1983). The subduction of oceanic crust foundered in Mid-Eocene between these two blocks. This oceanic crust of Tethys remained in progress northerly beneath Eurasian Plate (beneath both of these two blocks) Late Cretaceous onward and forming the Makran Subduction Zone. Moreover, Byrne and Sykes, (1992) represented that a high volume of sediment accretion begin by the convergence and uplift of Indian Plate at eastern Makran which caused an extension of $300 \mathrm{~km}$ to the upper plate by this accretion.

The Helmand and the Lut blocks are believed to be the arcward regions influencing the ongoing tectonism of Makran. On the other hand, an azimuth of north 10 degree east of the Arabian Oceanic Crust is being used up in Makran Subduction Zone (Byrne and Sykes, 1992). The velocity of convergence has been observed as $42.0 \mathrm{~mm} / \mathrm{yr}$ at the Eastern Makran while $36.5 \mathrm{~mm} / \mathrm{yr}$ at the Western Makran (DeMets et al., 1990). This resulted several structural modification within the accretionary prism including Chaman Fault and its southern members and Ornach-Nal Fault and the birth of active mud volcanoes along strike (Fig. 1). This study aims to focus on the active mud volcanoes, their nature and characteristics in Makran Coastal Zone.

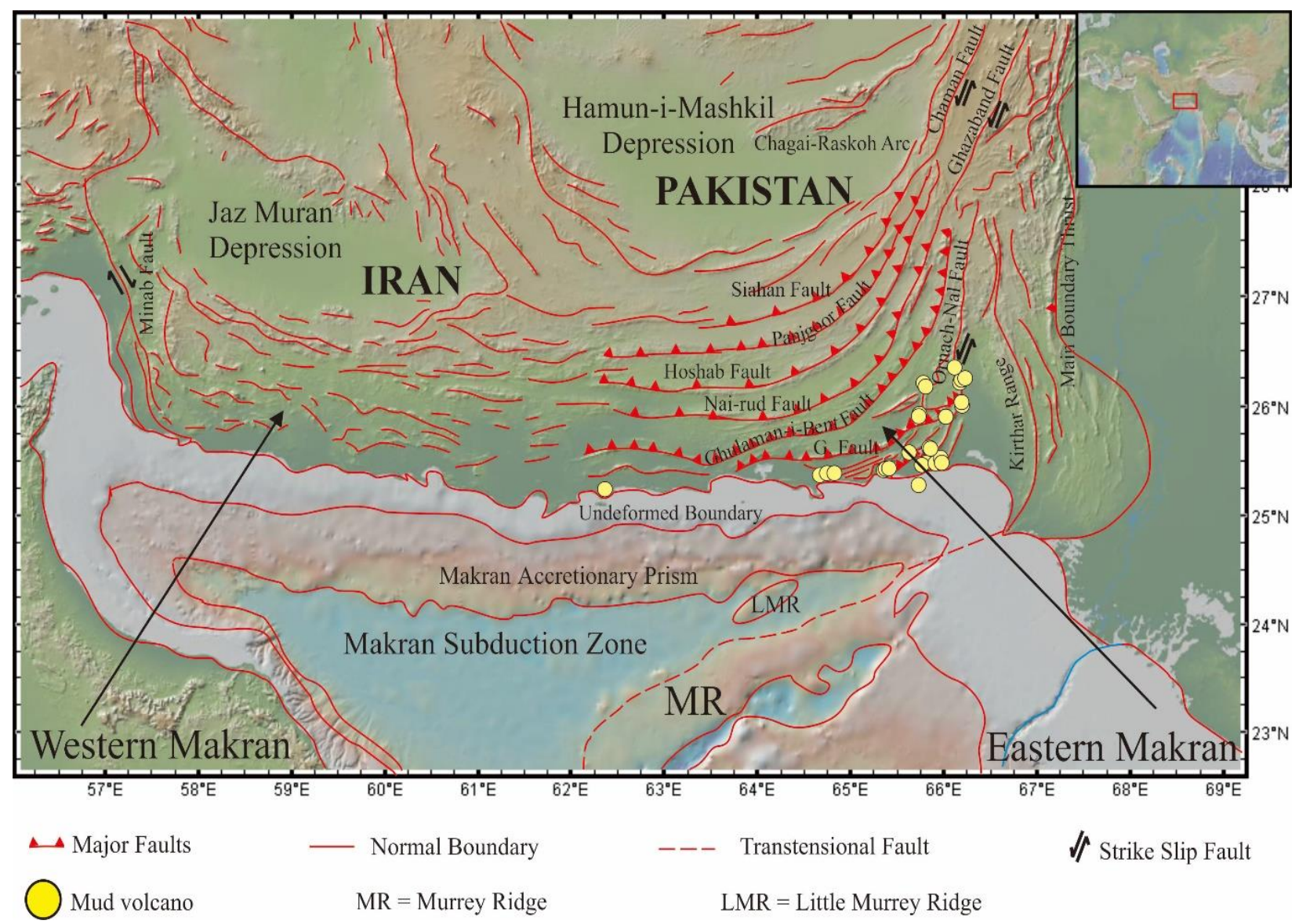

Figure 1: Represents the regional structure of Makran zone where it is bound by Ornach Nal

Fault at the east in Pakistan and Minab Fault at the west in Iran 


\section{Geological and Tectono-Morphic Framework}

The EW trend of Makran Subduction Zone is an exemplary zone in the world that stretches about $1000 \mathrm{~km}$ from east to west and has formed by the collision and convergence of Indian, Arabian and Asian Plates since Late Cretaceous (Byrne \& Sykes, 1992). The overall margin is divided into two segments i.e., the eastern segment in southern Pakistan and the western segment in the south eastern Iran. The eastern segment in Pakistan is bounded by a left lateral strike slip fault known as Ornach-Nal Fault (Fig. 1) (Kopp et al., 2001). This eastern segment stretches a length of $400 \mathrm{~km}$ in Pakistani region with an observable amount of low seismic but maximum values of earthquakes. One of the disastrous earthquakes of $8.1 \mathrm{Mw}$ which occurred in 1945 in this region. In general, the activity of seismic patterns probably appears prior to major quakes in eastern Makran and events of smaller increasing activity precede large. Such as, earlier a decade of 1945 mega quake, an increase seismic activity was observed in the region (Byrne \& Sykes, 1992). On the other hand, western segment is bound by Minab Fault system a right lateral fault system (not well enough to generate great tsunamigenic quakes). The stratigraphy of the region is quite interesting. The region has a stratigraphy starting from a Cretaceous Wakai mélange to a recent Haro Formation (Tab. 1). Snead, (1967) divided the coast into three geomorphic divisions; (a) steep and rocky cliffs interspersed by minor range beaches (b) sandy beaches (wide) supported with desert alluvial plains and (c) delta sections composed of clays and finer silts. Additionally, numerous mud volcanoes have emerged along the coast. They might be considered the largest in the world (Snead, 1967).

Table 1: Represents the stratigraphy of Makran Region [modified after Kassi et al., 2013; Kassi et al. 2007; Cheema et al., 1977; Hunting Survey Corporation, (1961)]

\begin{tabular}{|l|l|l|l|}
\hline Group & Formation & Age & Lithology \\
\hline \multirow{4}{*}{$\begin{array}{l}\text { Makran } \\
\text { Group }\end{array}$} & Haro formation & $\begin{array}{l}\text { Pleistocene } \\
\text { Holocene }\end{array}$ & $\begin{array}{l}\text { Conglomerate, sandstone, shelly, reefoid } \\
\text { limestone }\end{array}$ \\
\cline { 2 - 4 } & \multicolumn{3}{|c|}{ Unconformity } \\
\cline { 2 - 4 } & Ormara Formation & Late Pliocene & $\begin{array}{l}\text { Poorly consolidated soft mudstone, sandstone } \\
\text { in lesser quantity }\end{array}$ \\
\hline \multirow{4}{*}{$\begin{array}{l}\text { Turbat } \\
\text { Group }\end{array}$} & Chatti Formation & Early Pliocene & Calcareous shale, marl \\
\cline { 2 - 4 } & Hinglaj Formation & Late Miocene & Shale and sandstone (cyclic succession) \\
\cline { 2 - 4 } & Parkini Mudstone & Early Miocene & Mainly mudstone and thin sandstone \\
\cline { 2 - 4 } & Fonjgur & Olig.-Miocene & Shale and interbedded sandstone \\
\cline { 2 - 4 } & Hoshab Shale & Lt. Eocene & Mainly shale and thin sandstone \\
\cline { 2 - 4 } & Er.Oligocene & Thrust \\
\cline { 2 - 4 } & Wakai Limestone & Eocene & $\begin{array}{l}\text { High quantity of fossils and reefoid } \\
\text { Limestone }\end{array}$ \\
\hline \multirow{3}{*}{$\begin{array}{l}\text { Wakai- } \\
\text { Ispikan } \\
\text { Group }\end{array}$} & Ispikan Formation & Paleocene & $\begin{array}{l}\text { Sandstone, conglomerate and lesser quantity of } \\
\text { shale }\end{array}$ \\
\cline { 2 - 4 } & Wakai mélange & $\begin{array}{l}\text { Cretaceous- } \\
\text { Paleocene }\end{array}$ & $\begin{array}{l}\text { Ultamafic and mafic rocks, marble, pelagic } \\
\text { limestone, chert, marl, shale agglomerate }\end{array}$ \\
\cline { 2 - 4 } & &
\end{tabular}




\section{Active Mud Volcanoes}

The zone has been previously studied and reported by (Kassi et al., 2013; Delisle 2004 and 2002; Wiedicke et al., 2001; Tabrez et al., 1999; Snead, 1964; Sondhi, 1947). The mud volcanoes befall at numerous localities for instance Awaran, Bela, Gwadar, Kund Malir, Ormara and a few other places (Fig. 1). Additionally, Tebrez et al., (2002) reported that these are found throughout the coastal extension starting from Jiwani to Sonmiani (from west to east of the coast in Pakistan). A total of 70 mud volcanoes are identified. These are mostly active screening two to five identifiable chapters by their deposits. The mud volcanoes are distributed in seven clusters and fourteen subclusters (Table 2). The active zone of mud volcanoes runs analogous to the main trend i.e. E-W. Each cluster epitomizes a certain quantity of mud volcanoes. Furthermore, they densely transpire in the east due to the rate of convergence of plate easterly increasing and frequently thrust-affiliated manifestations. Withal, the mud volcanoes and diapirs' distribution and expansion are meticulous by thrust related with anticlines of asymmetrical (Schluter et al., 2002). Compositionally, these are foremost mudstone and the age ranges from lower Miocene to Pleistocene and/or older (Kassi et al., 2013) but Snead (1964) mentioned that these mud volcanoes have an age of Pleistocene by examining the young eruptive material.

\subsection{Awaran and Sipai-Sing Clusters}

Kassi et al., (2013) elaborated these clusters and were not mentioned before. Awaran Hills comprise a total of 20 mud volcanoes which are situated at SW and W of Bela town. They cover an area of $58 \mathrm{~km}$ along the strike and divided into North and South Awaran Hills and Sipai-sing clusters (Tab. 1). The maximum covered are is about 336.2 ha with a diameter of the craters from less than one meter to more than eighty-five meters. Further, Sipai-sing sub-cluster is composed of 3 older mud volcanoes. They are mostly active and represent mud flows of 2 to 5 chapters.

\subsection{Chandragup Cluster}

Chandragup is the largest of the area which exists since 1840 without any change in its extrusions and geomorphology (Tabrez et al., 2002) (Fig. 3). It covers a region of 2-8 km SE of Hingol River. It is composed of 11 mud volcanoes and a few dried up. Furthermore, it is divided into three subclusters namely North, South and West Chandragup (Kassi et al., 2013; Delisle 2004 and 2002; Wiedicke et al., 2001; Snead, 1964). Some of them mound-like are not active. The covered area of the mud volcanoes extends from 1.70 to 1921 ha with a crater diameter of 9 to 118 meters. Additionally, 8 of them are active among North and South Chandragup (Kassi et al., 2013). The banishment seesaw and evicting hydrocarbon gases and fluidities mud but they have episodic activities which resemble 2 to 5 mud flows chapters. Bubbles of mud are observed and from time to time also spurt pugnaciously due to arising hydrocarbon gases at C-1 which has a crater 20 meters in diameter. C-2 at South Chandragup which is a water-filled lake circularly, displays weak expel and negligible activities. Furthermore, erosion caused drain of water and it proceeds to wear away the older deposits. C-3 with a diameter of 30 meters has dried up. 


\subsection{Gwadar Cluster}

It is located nearby Gwadar city (Delisle et al., 2002) (Fig. 2). The area sheltered by the focal mud volcano is approximately 0.11 ha and crater diameter ranges from 1 to $7 \mathrm{~m}$. A total of two mud volcanoes have been recognized which exemplifies no activities (Kassi et al., 2013).

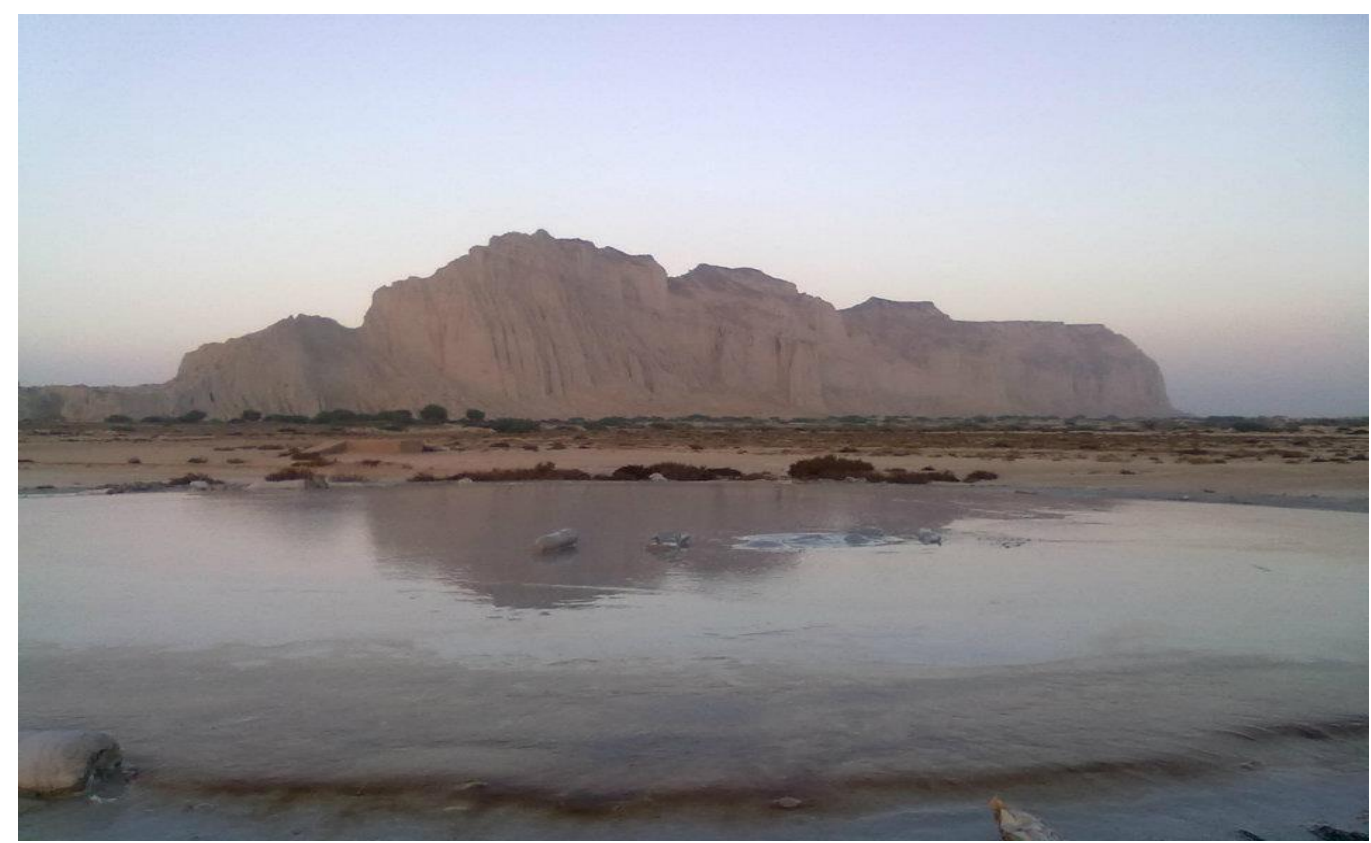

Figure 2: Illustrates a close-up view of Gwadar mud volcano.

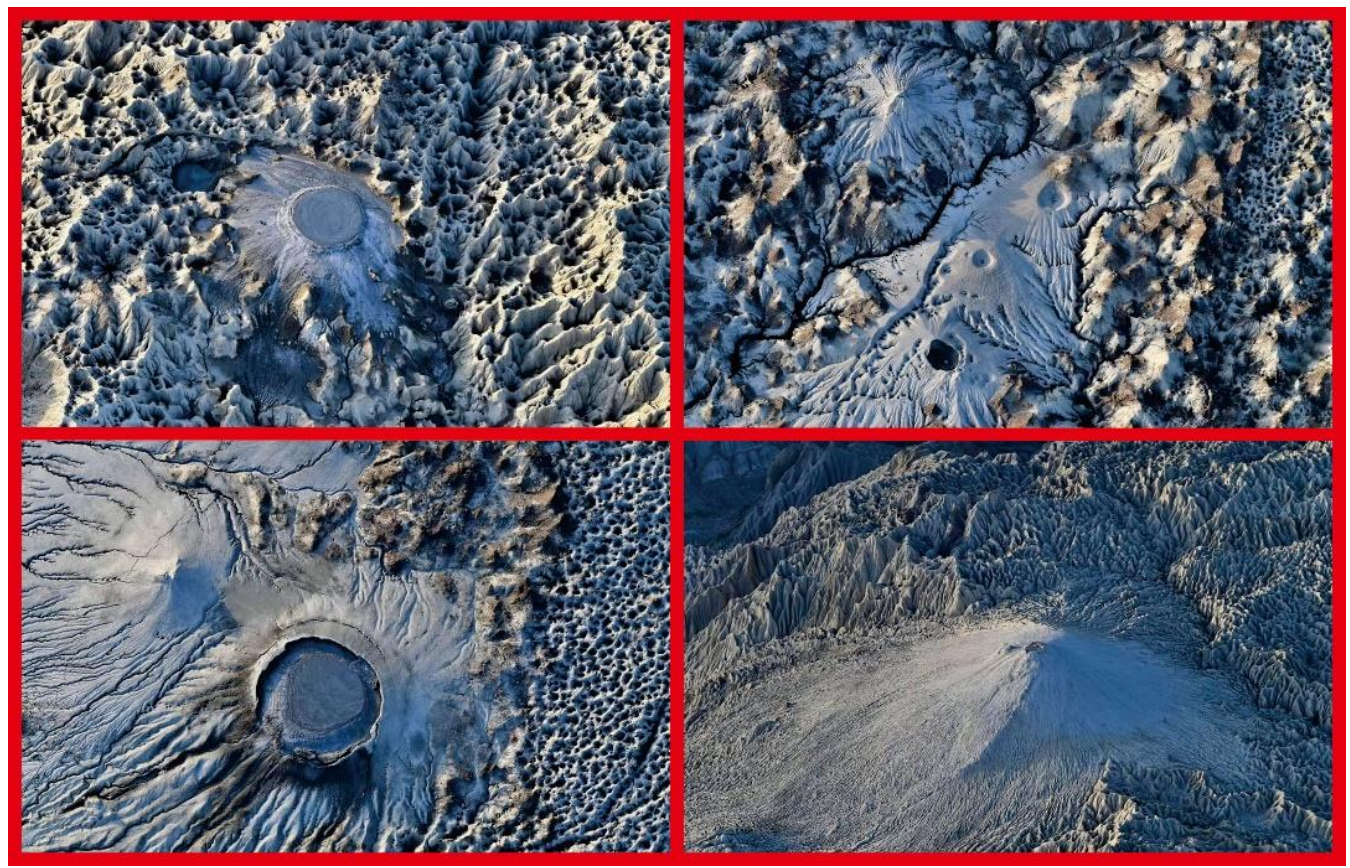

Figure 3: Signifies chandragup mud volcanoes and surrounding mudflows 


\subsection{Jabal-E-Gurab Cluster}

This cluster is made by playa-like sediments which is situated $1 \mathrm{~km}$ at western part of Dhak Anticline in Dhak Desert (Reimann, 1989). Dhak is a local word that means flat area. Kassi et al., (2013) distinguished 4 minor mud volcanoes in this zone of cluster whereas numerous mound-like mud volcanoes were also recognized (Reimann, 1989). It concealments an area of 0.6 to 02.6 ha with an observed diameter of craters about 1.5 to 11 . Their existence show consequence tectonic features. A uniform top mud volcano symbolizes hummocky hill bounded by numerous minute craters with bubbly mud and gas release.

\subsection{Khandewari Cluster}

It is situated at north-north-east to south-south-west trend Haro Range which is about 30 kilometers away from sub-cluster South Chandragup (Kassi et al., 2013). This cluster is composed of 6 mud volcanoes which exist analogous to the strike. Furthermore, these are distributed into North and South Khandewari sub-clusters. A spherical cone shaped huge mud volcano is recognized at North Khandewari sub-cluster. The area covered by this cluster ranges from 0.09 to 308.2 ha and a craters diameter of 13.5 and upto $138 \mathrm{~m}$. Almost all discharge fluidities mud periodically and are active whereas showing mud flows of 2 to 5 chapters (Kassi et al., 2013).

\subsection{Kund Malir Cluster}

This cluster is situated at coastal Highway about $5 \mathrm{~km}$ NE of Kund Malir Village. There have been 16 mud volcanoes in $5 \mathrm{~km}$ zone with a strike of NE-SW trend. The cluster covers an area of 0.04 to $118.6 \mathrm{ha}$. The largest crater is $25 \mathrm{~m}$ in diameter. They are mostly active (Kassi et al., 2013).

\subsection{Ormara Cluster}

These clusters were also mentioned by (Kassi et al., 2013). They are situated at N-NE of Ormara town with a distance of about $10 \mathrm{~km}$. The cluster is grouped into 3 sub-clusters following EW trend on a flat area. A total of 11 mud volcanoes are observed which cover an area from 0.06 to 20.92 ha with a diameter of the craters from 1.0-67 m. They are said to be active.

\subsection{Offshore Mud Volcanoes}

Sondhi, (1947) recognized three mud islands in the offshore Makran accretionary wedgeat deeper and shallow shelf parts. These have been linked with the historical earthquake of $8.2 \mathrm{Mw}$ off the coast of Makran in November 1945 for instance Malan Island.

Table 2: Characterizes clusters/sub-clusters of mud volcanoes (Modified after Kassi et al., 2013).

\begin{tabular}{|l|l|c|c|c|}
\hline \multirow{2}{*}{ S. No. } & Cluster Name & $\begin{array}{c}\text { Crater range diameters } \\
(\mathbf{m})\end{array}$ & $\begin{array}{c}\text { Covered areas } \\
(\mathbf{h a})\end{array}$ & Quantity \\
\hline \multirow{2}{*}{$\mathbf{1}$} & AwaranHills (North) & $1.0-7.5$ & $0.13-336.2$ & 9 \\
\cline { 2 - 5 } & Awaran Hills (South) & $1.0-10.5$ & $0.03-265.7$ & 8 \\
\cline { 2 - 5 } & Sipai-sing & $5.0-85$ & $0.19-10.21$ & 3 \\
\hline \multirow{2}{*}{} & Chandragup (North) & $9.0-118$ & $01.70-1921.0$ & 5 \\
\hline
\end{tabular}




\begin{tabular}{|l|l|c|c|c|}
\hline & Chandragup (South) & $22.5-145$ & $11.90-138.0$ & 4 \\
\cline { 2 - 5 } & Chandragup (West) & $108.0-112$ & $43.70-64.5$ & 2 \\
\hline $\mathbf{3}$ & Gwadar & $1.0-7$ & $0.11-00.46$ & 2 \\
\hline $\mathbf{4}$ & Jabal-u-Ghurab & $1.5-11$ & $0.60-02.6$ & 4 \\
\hline $\mathbf{5}$ & Khandewari (North) & $13.5-110$ & $0.09-308.2$ & 3 \\
\cline { 2 - 5 } & Khandewari (South) & Up to 138 & $41.00-163.4$ & 3 \\
\hline $\mathbf{6}$ & Kund Malir & $1.0-4.5$ & $0.04-118.6$ & 16 \\
\hline $\mathbf{7}$ & Ormara (East) & $1.0-67$ & $0.63-20.92$ & \\
\cline { 2 - 5 } & Ormara (Central) & $1.0-30$ & 10.5 & 1 \\
\cline { 2 - 5 } & Ormara (West) & $1.0-6$ & $0.06-00.47$ & 4 \\
\hline
\end{tabular}

\section{Discussion}

The occurrence of offshore and onshore mud volcanoes are considered in different phases throughout Makran coastal area which represent a Pleistocene age probably older. In Addition, the mudstone color of older mud volcanoes seems to be greenish gray to bluish green numerous locales of the active zone (Kassi et al., 2013). The active mud volcanoes have resemblances with the mud volcanoes found at the "Bay of Bengal", further confirmation is the similarity of Tertiary sandstones, shales and mudstones on the eastern arc of Himalaya. Both Himalayan arc and Makran Subduction Zone are experiencing active faulting and they undergo rapid sedimentation (Snead, 1964).

The continental margin of Makran has an ideal environment of Oxygen Maximum Zone which receives organic rich matters in its sediments by marine organisms. This framework making it suitable for the discharge of methane related fluidities through onshore and offshore vents. For instance, biogenic related invariable methane gasses are released from Jabel-e-Gurab and Chandragup mud volcanoes (Fig. 3), while the mud volcano in Ormara discharges thermogenic type of fluidities. Further, the mud volcanoes in the offshore regions also discharge bacterial type of fluidities (Tabrez et al., 2002).

In general, the sands and silts which are heavier overlain the plastic clay bring the eruptions through vents of mud volcanoes. Such a condition brings the plastic clay upward by thrust faulting. The tectonic activities or and/or relevant phenomena create imbalance pressure in sedimentary environment and this increased pressure boost the migration of fluid and discharge the fluidities upward in the weaker zones.

Moreover, Snead (1964) expressed that gas is not the basic cause of discharging the fluidities but plays an assisting role to extrude the fluidities and act as a lubricant agent for bubbles formation as seen and heard when the eruptions take place in Makran. Such loud noise by active mud volcanoes is heard in Makran is due to the methane gas escape. On the other hand, the gas is not the only factor of assisting, salt water, tectonic stress and oil also assist for this natural process. (Snead, 1964). Light gravity oil assist to form the mudflows and water can replace oil when it is in a little quantity (Kugler, 1933). Therefore, the offshore water is assisting the mud volcanoes in Chadragup clusters and adjacent mud volcanoes. In addition, the rain and river waters transmitting water also boost the pressure and assist to eruption of fluidities. In addition, the mud volcanoes of Makran fall near the active faults (Fig.1) and it is believed that earthquake activities are playing 
the major roles in these eruption processes. Approximately 3 quarters of eruptions are caused by earthquakes in Makran zone.

\section{Conclusion}

The active mud volcanoes are located along strike in the Eastern Makran in Pakistan. An age proposed for these mud volcanoes is Late Miocene to Pleistocene. A total of 70 mud volcanoes are recognized which are distributed into seven clusters and fourteen sub-clusters. Among them, Chandragup is considered as the oldest and biggest active mud volcano in the region. The Jabele-Gurab, Chandragup and offshore mud volcanoes discharge methane related fluidities i.e. biogenic gasses the mud volcano in Ormara discharges thermogenic type gasses. The heavier sands and silts at the surface overlain the plastic clay which brings pressure imbalance due to tectonic activities and bringing up the plastic clay upward. In addition, several factors are responsible for the eruption of fluidities for instance, oil, saltwater, freshwater from rain and rivers and tectonic stresses. The earthquake activities are approximately $75 \%$ responsible for making these stresses and boosting the pressure and resulting in eruptions of fluidities.

\section{References}

[1] Byrne, D. E., Sykes, L. R., \& Davis, D. M. (1992). Great thrust earthquakes and aseismic slip along the plate boundary of the Makran subduction zone. Journal of Geophysical Research: Solid Earth, 97(B1), 449-478.

[2] Cheema M R, Raza S M, Ahmad H (1977) Cenozoic: in Shah, S. M. I. (ed.), Stratigraphy of Pakistan: Geol. Surv. Pakistan, Quetta, Mem 12:56-98

[3] Delisle G (2004) The mud volcanoes of Pakistan. Environ Geol 46:1024-1029

[4] Delisle G, Von Rad U, Andruleit H, Von Daniels CH, Tabrez AR, Inam A (2002) Active mud volcanoes on- and offshore eastern Makran, Pakistan. Int J Earth Sci 91:93-110

[5] DeMets, C., Gordon, R. G., Argus, D. F., \& Stein, S. (1990). Current plate motions. Geophysical journal international, 101(2), 425-478.

[6] H. G. Kugler: Contribution to the Knowledge of Sedimentary Volcanism in Trinidad, jouris. Inst,1. of Petroleum Technologists, Vol. 19, London, 1933, pp. 743-772 (discussion, pp. 760-772); reference on pp. 765-767.

[7] Hunting Survey Corporation Ltd. (1961) Reconnaissance geology of part of West Pakistan.Miracle Press. Ottawa, Ontario, Canada, pp 1-550

[8] Kassi AM, Khan AS, Kasi AK (2007) Newly proposed Cretaceous-Palaeocene lithostratigraphy of the Ispikan-Wakai area, Southwestern Makran, Pakistan. Pak J Himal Earth Sci 40:25-31

[9] Kassi, A. M., Khan, S. D., Bayraktar, H., \& Kasi, A. K. (2014). Newly discovered mud volcanoes in the Coastal Belt of Makran, Pakistan - tectonic implications. Arabian Journal of Geosciences, 7(11), 4899-4909.

[10] Kopp C, Fruhn J, Fluh ER, Reichert C, Kukowski N, Bialas J, Klaeschen D (2001) Structure of theMakran subduction zone from wide-angle and reflection seismic data. Tectonophysics 329:171191

[11] Reimann KU (1989) Makran Coastal Range, Field Report No. 8. Hydrocarbon Development Institute of Pakistan, German Advisory Group, Islamabad (BGR Archive No. 0115480)

[12] Schluter HU, Prexl A, Gaedicke C, Roeser H, Reichert C, Meyer H, von Daniels C (2002) The Makran accretionary wedge: sediment thicknesses and ages and the origin of mud volcanoes. Mar Geol 185: 219-232

[13] Snead RE (1964) Active mud volcanoes of Baluchistan, West Pakistan. Geogr Rev 54:546-560 
[14] Snead, R. E. (1967). Recent morphological changes along the coast of west pakistan 1. Annals of the Association of American Geographers, 57(3), 550-565.

[15] Sondhi VP (1947) The Makran earthquake of 28th November 1945: the birth of new islands. Indian Mineral 1:154-156

[16] Tabrez AR, Inam A, Amjad S (1999) Birth of an island "Malan" off Hingol River, Makran, Balochistan. Biosphere 8:14-15

[17] Tabrez, A. R., Delisle, G., von Rad, U., Inam, A., \& Rabbani, M. M. Mud volcanoes of the makran coast: the future potential energy resource of pakistan.

[18] Tirrul, R., Bell, I. R., Griffis, R. J., \& Camp, V. E. (1983). The Sistan suture zone of eastern Iran. Geological Society of America Bulletin, 94(1), 134-150.

[19] WiedickeM, Neben S, Spiess V (2001) Mud volcanoes at the front of the Makran accretionary complex, Pakistan. Mar Geol 172:57-73

*Corresponding author.

E-mail address: khanw@ mail2.sysu.edu.cn 